\title{
Occurrence of adult anchovy in Catalonia (NW Mediterranean) in relation to sea surface conditions
}

\author{
Federico Quattrocchi, Valeria Mamouridis, Francesc Maynou \\ Institut de Ciències del Mar, CSIC, Psg. Marítim de la Barceloneta 37-49, 08003-Barcelona, Spain. \\ E-mail: quattrocchi@icm.csic.es
}

\begin{abstract}
Summary: Generalized additive and generalized additive threshold models were used to study the relationship between landings per unit effort (LPUE) of anchovy, Engraulis encrasicolus, during the spawning season (May-October) from 20002010, and environmental variables, using sea surface data derived from satellite imagery (temperature, salinity, chlorophyll $a$, and meridional and zonal velocity current) in three fishing zones defined along the Catalan coast. The configuration of the environment where spawning aggregations occur affects early life stages and therefore the future demographic structure of the population. It is therefore fundamental to define the environmental conditions and their variations during the spawning season. Our results show that the low salinity in the Northern and Central sector and the velocity of the zonal and meridional currents in the Central and Southern sector, respectively, implicated in retention processes, increase LPUE during the spawning period. Temperature was related to LPUE in the Southern and in the Northern sectors, in both of which a non-linear positive effect with a local maximum peak at lower temperature values was present. However, in the Northern sector, this relationship held only for the period before 2007. After 2007 the decrease in preferred temperature suggests a reduction of the thermal window in which adult spawner aggregations occur. In agreement with previous studies on this species, the relationships were non-linear, stressing the importance of the match in timing and location between favourable conditions and spawning period as a crucial event for understanding the dynamics of small pelagics populations.
\end{abstract}

Keywords: Engraulis encrasicolus; NW Mediterranean; environmental conditions; anchovy landings; generalized additive models.

Ocurrencia de anchoa adulta en Cataluña (Mediterráneo noroccidental) en relación a las condiciones superficiales del mar

Resumen: Con el objeto de estudiar la relación entre descargas por unidad de esfuerzo (LPUE) de la anchoa, Engraulis encrasicolus, durante la época de puesta (Mayo-Octubre) y variables ambientales marinas obtenidas por observación de satélite (temperatura, salinidad, clorofila-a, velocidad de corriente zonal y meridional) se analizaron series de datos para el periodo 2000-2010 mediante modelos aditivos generalizados, con y sin umbral, en tres zonas de pesca de la costa catalana. La configuración del ambiente en que ocurren las agregaciones de puesta afecta a los estadios tempranos y, por consiguiente, a la estructura demográfica futura de las poblaciones. Por lo tanto es de gran importancia definir las condiciones ambientales y sus variaciones durante la época de puesta. Los resultados del análisis muestran que bajas salinidades en los sectores norte y central, y las velocidades zonal y meridional de la corriente, en los sectores central y sur respectivamente, implicadas en los procesos de retención hacen aumentar la LPUE durante el periodo de puesta. La temperatura se relacionó con la LPUE en los sectores sur y norte. En ambas zonas se observó un efecto positivo y no lineal con un pico máximo a valores de temperatura bajos. Sin embargo, en el sector norte esta relación se mantuvo solamente hasta 2007. Después de 2007, la disminución en la temperatura preferencial sugiere una reducción en la ventana térmica en la que ocurren las agregaciones de puesta. Las relaciones obtenidas son no lineales, coincidiendo con estudios previos en esta especie, haciendo resaltar la importancia del ajuste espacio-temporal entre condiciones favorables y periodo de puesta como evento crucial para entender la dinámica poblacional de los pequeños pelágicos.

Palabras clave: Engraulis encrasicolus; Mediterráneo noroccidental; condiciones ambientales; descargas; Modelos Aditivos Generalizados.

Citation/Como citar este artículo: Quattrocchi F., Mamouridis V., Maynou F. 2016. Occurrence of adult anchovy in Catalonia (NW Mediterranean) in relation to sea surface conditions. Sci. Mar. 80(4): 457-466. doi: http://dx.doi.org/10.3989/ scimar.04413.24A

Editor: S. Somarakis.

Received: February 1, 2016. Accepted: June 22, 2016. Published: October 25, 2016.

Copyright: (9 2016 CSIC. This is an open-access article distributed under the terms of the Creative Commons Attribution (CC-by) Spain 3.0 License. 


\section{INTRODUCTION}

Small pelagic fishes are key components of marine ecosystems and support fisheries of global importance (Alheit et al. 2012). These organisms are characterized by a short life span (2-3 years) and they feed on phytoplankton and small zooplankton (Tudela and Palomera 1995) in a short plankton-based food web. Populations of these fishes experience large interannual and long-term variations in abundance (Lluch-Belda et al. 1989), and several hypotheses have been formulated in order to explain these fluctuations (e.g. the "matchmismatch" hypothesis (Cushing 1990); the "optimal environmental window" (Cury and Roy 1989); and the "ocean triad" (Bakun 1996, Agostini and Bakun 2002)). These hypotheses highlight the importance of suitable environmental conditions in time and location during early life stages (eggs and larvae) for recruitment success and failure. Since early life stages are characterized by high sensitivity to environmental changes (Pörtner and Peck 2010), small variations in growth and survival rates of these stages could generate large differences in the annual recruitment (Houde 1997) and therefore in the future structure of the adult population. It is therefore fundamental to define the environmental conditions and their variations during the spawning period of these species.

In the northwest Mediterranean, the anchovy, Engraulis encrasicolus (Linnaeus, 1758), is the most important small pelagic fish in terms of biomass along with the pilchard, Sardina pilchardus (Walbaum, 1792) (Lleonart and Maynou 2003). Anchovy ageat-first-maturity is 1 year in the area $(\mathrm{Lm}>9 \mathrm{~cm} \mathrm{TL})$ (Pertierra 1992) and $88 \%$ of individuals are mature at age 0 (Cardinale et al. 2010)). Anchovy spawns in late spring and summer in coastal waters of continental origin characterized by low salinity (Lloret et al. 2004, Palomera et al. 2007, Sabatés et al. 2007a, 2013). The time of spawning is linked to temperature and, as for species that reproduce in spring/summer, spawning starts earlier in the Southern than in the Northern sector because the surface temperature increases earlier in the south and later extends northwards. For this same reason, the spawning period is longer in the south, where temperatures decrease more slowly (Martín and Sabatés 1991, Martín et al. 2008).

Two main spawning grounds characterize the NW Mediterranean: one is located in front of the Ebro delta and the other one in the Gulf of Lions up to the Rhône delta. Both areas are highly productive and characterized by relatively low salinity due to river runoff if compared with adjacent areas (Palomera et al. 2007). Early stages of development of the anchovy are favoured by these highly productive, low-salinity waters and also by mesoscale structures such as eddies (e.g. Palomera et al. 2007, Sabatés et al. 2013), which appear along the Northern Current coming from the Gulf of Lions (Millot 1991, Rojas et al. 1995). Both conditions cause a greater concentration of nutrients, phytoplankton and zooplankton compared with other areas (e.g. Razouls and Kouwenberg 1993, Bakun 2006, Sabatés et al. 2007a, Martín et al. 2008). In previous studies, abundance fluctuations of the anchovy have been associated with local environmental conditions and climate variability (e.g. Lloret et al. 2001, 2004, Martín et al. 2008, 2012). Thus, the positive trends in temperature and salinity data observed during the second half of the twentieth century in the western Mediterranean Sea (Calvo et al. 2012, Vargas-Yáñez et al. 2009, 2010) could have affected the population dynamics of this small pelagic fish.

In the Catalan Sea, the anchovy fishery is concentrated mostly between Cape Creus and the Ebro river delta (Agostini and Bakun 2002); it is carried out for 10 months per year (close season: December-January, generally) and 5 days per week (Pertierra and Lleonart 1996). Discards of this species are negligible (Lloret et al. 2004). Anchovy is caught mainly in spring/summer, when a significant fraction of the population is mature (Cardinale et al. 2010) and has incorporated the recruits from the previous year's spawning, so landings in these seasons can be considered as a proxy of the abundance of adult spawners (e.g. Martín et al. 2008).

The catches in the geographical subarea 06 (GSA06) in the period 1990-2010 were highly variable, suffering a continuous decrease after 1994, with a minimum of $1900 \mathrm{t}$ in 2007 and an average of $11700 \mathrm{t}$, with two recoveries in 2002 and 2009 (Cardinale et al. 2010). Also, Farrugio (2013) reported decreasing trends in anchovy biomass in the Gulf of Lions between 2001 and 2005 and along the Catalan coasts, where this trend continued until 2010. Cardinale et al. (2010) described the status of this species as overexploited in GSA06, but the decrease and fluctuations in abundance cannot be attributed only to the fishing activities but to a combined effect of overexploitation and unfavourable environmental conditions (e.g. Martín et al. 2008, 2012, Lloret et al. 2000, 2001).

Coupling catches and oceanographic information is one of the main objectives in fisheries science and management. Tools such as generalized additive models (GAMs, Hastie and Tibshirani 1990, Wood 2006) allow these relationships to be described thanks to their flexibility, which allows the non-linear effect of a variable to be assessed independently from the value of another covariate (i.e. additivity). Because of this, they have been largely used in the Mediterranean Sea (e.g. Martín et al. 2008, Bellido et al. 2008, Giannoulaki et al. 2013). A variant of the GAM is the threshold GAM (TGAMs, Ciannelli et al. 2004). Using this modelling approach, composed of two additive formulations, it is possible to test whether a covariate effect changes according to two levels, which are defined by a threshold, of another variable (i.e. non-additive interaction). Therefore, the comparison of the results from the GAM and the TGAM allows us to assess, apart from nonlinear relationships, whether the effects of the environmental variables are additive or not.

Through the use of both GAM and TGAM, this study aims to investigate the relation between the anchovy fishery landings and the local environmental conditions in the NW Mediterranean Sea during the spawning season, considering landings per unit of effort (LPUE) as a proxy of abundance of the adult 


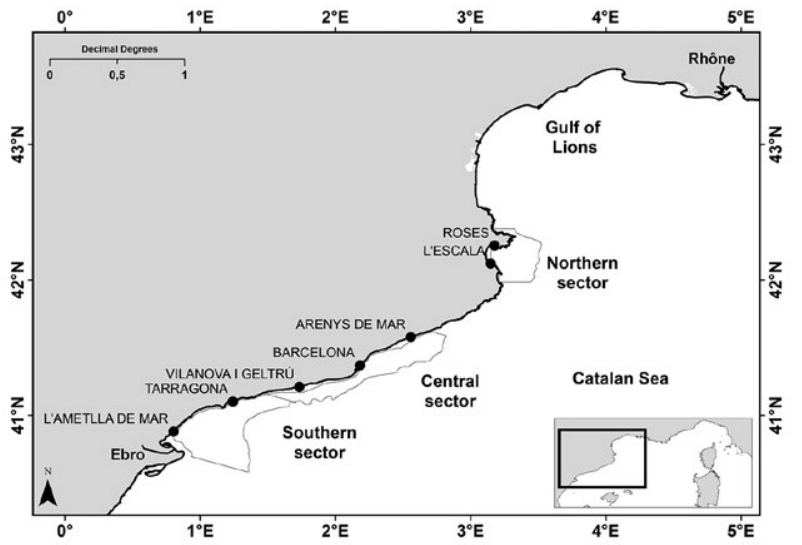

Fig. 1. - The study area divided into three sectors (Southern, Central and Northern) limited by the $35 \mathrm{~m}$ and $200 \mathrm{~m}$ isobaths and their major fishing ports.

population (spawners), in order to determine potential exogenous drivers of the population spatio-temporal dynamics of this small pelagic fish.

\section{MATERIALS AND METHODS}

\section{Study area}

The study area is located in the Catalan Sea, NW Mediterranean (Fig. 1). The area is characterized by a permanent shelf-slope density front, separating open-sea high-salinity waters from low-salinity continental shelf waters, and a geostrophic Northern Current which flows southwestwards roughly parallel to the coast with an overall transport of around $1 \mathrm{~Sv}$ (Castellón et al. 1990). The NW Mediterranean coast receives significant freshwater runoff from two major rivers, the Rhône and the Ebro. The Rhône discharges at the east of the Gulf of Lions and enhances the shelf-slope front by lowering the salinity of shelf waters. The Ebro, with lower runoff, also decreases the salinity of the waters on the relatively wide shelf near its mouth at the southern limit of the area. The water column structure shows a marked seasonal cycle, well mixed in winter and strongly stratified in summer, during the anchovy spawning season, when primary production is limited to a deep chlorophyll maximum (DCM), a thin layer at the deepest levels of

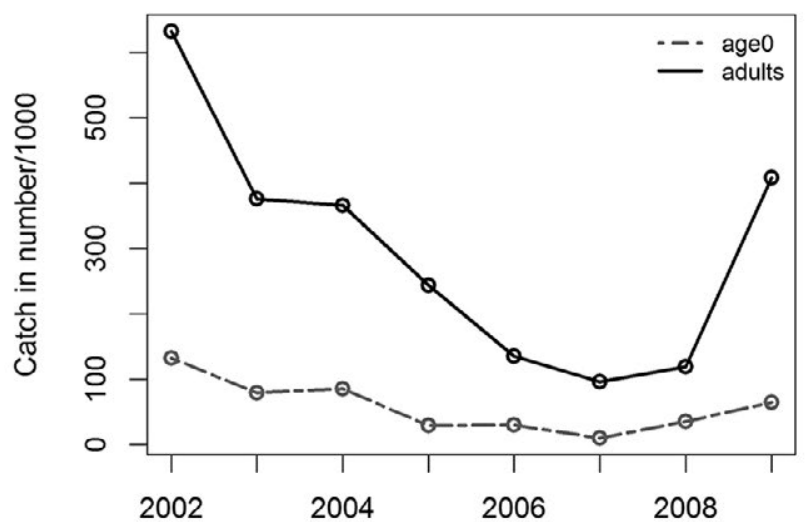

the photic zone, ca. $60 \mathrm{~m}$ depth (Estrada et al. 1985). Another contribution to local productivity results from freshwater river runoff, which can enrich coastal waters near major river mouths. Summer productivity conditions are highly dependent on interannual variability in temperature and salinity, which in turn depends on the heat balance of air-sea exchanges in the region and fresh water runoff, which are variable from one year to the next. The environmental characteristics and the daily displacement of the fishery operation were used to define three sectors in the study area, Northern, Central and Southern, according to Martín et al. (2008) (Fig. 1). These sectors were limited by the $35 \mathrm{~m}$ and $200 \mathrm{~m}$ isobaths, which represent the longitudinal expansion where the anchovy fishery is carried out.

\section{Data}

Monthly landings $(\mathrm{kg})$ from the main ports with a purse seine fleet (a total of 90 vessels) (Fig. 1) were used to analyse the variations in abundance of $E$. encrasicolus during the period 2000-2010. Landings data for each sector (Northern, Central and Southern sector) were obtained from the daily fish sale database of the Fisheries Directorate of the Autonomous Government of Catalonia. LPUE were computed by dividing the total monthly landings in each sector by the total number of vessels that carried out fishing operations (LPUE as $\mathrm{kg} /($ vessel $\times$ day $))$. The part of the data set analysed represents the whole anchovy spawning period, considered to be from May to October (Palomera 1992, García and Palomera 1996). This period also coincides with the period when most anchovy is caught $(62 \%$ $83 \%$ of the total annual catch in weight). The average monthly landings and effort are summarized in Table 1. The technical characteristics of the purse seine fleet operating in the area are $18.7 \mathrm{~m}$ length-overall (min. 12, max. $25 \mathrm{~m}$ ), tonnage $37.7 \mathrm{GT}$ (min. 20, $\max 78 \mathrm{GT}$ ) and engine power $209 \mathrm{~kW}$ (min. 155, $\max .447 \mathrm{~kW})$. Figure 2 shows the age composition of the landings in Geographic SubArea 6 (GSA06, the northern half of which corresponds to the study area), based on the 2010 stock assessment carried out by the Mediterranean subgroup of the Science, Technical, Economic Committee for Fisheries of the European Commission (Cardinale

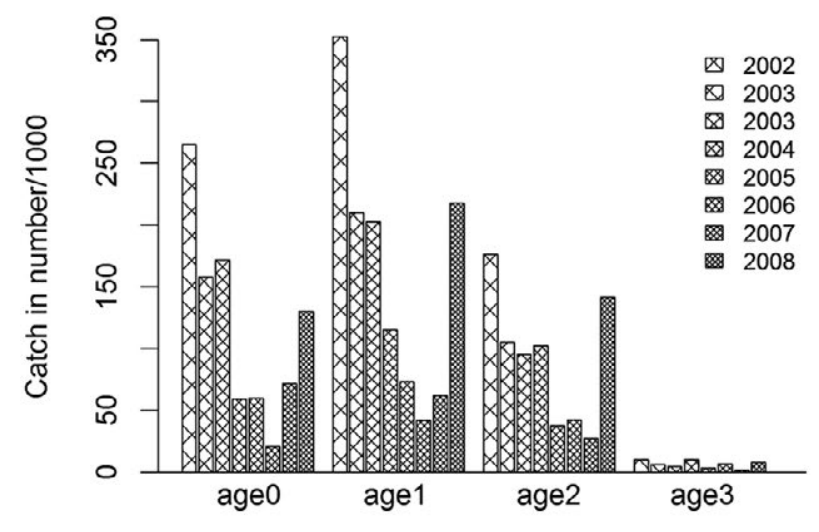

Fig. 2. - Left: Spawning individuals in age class 0 and age classes 1 and higher, assuming a maturity ogive $0.5,0.89,1,1$ for age classes 0 to 3 in GSA06 (Cardinale et al. 2010). Right: age class composition of landings (number of individuals) for the period 2002-2009 in GSA06 (Cardinale et al. 2010). 
Table 1. - Average anchovy landings (1) and fishing trips (monthly vessel*day) (2) in the three sectors for each year, during the May-October spawning period. All values are reported as mean \pm standard error (SE).

\begin{tabular}{|c|c|c|c|c|c|c|c|c|c|c|c|c|}
\hline & & 2000 & 2001 & 2002 & 2003 & 2004 & 2005 & 2006 & 2007 & 2008 & 2009 & 2010 \\
\hline \multirow{2}{*}{ North } & 1 & $255.3 \pm 78.1$ & $249.1 \pm 73.9$ & $265.9 \pm 72.8$ & $232.8 \pm 61.3$ & $121.1 \pm 52.1$ & $104.1 \pm 31.8$ & $106.5 \pm 30.1$ & $81.5 \pm 28.9$ & $100.4 \pm 21.1$ & $87.6 \pm 26.7$ & $91.1 \pm 27.4$ \\
\hline & 2 & $184.6 \pm 52.1$ & $148 \pm 34.8$ & $103.5 \pm 23.7$ & $155.3 \pm 44.7$ & $94.3 \pm 29.8$ & $76.5 \pm 22.7$ & $83.1 \pm 27.1$ & $66.5 \pm 16.7$ & $91.3 \pm 25.4$ & $82.6 \pm 23.2$ & $74.6 \pm 20.9$ \\
\hline \multirow{3}{*}{ Centre } & 1 & $69.8 \pm 25.9$ & $106.1 \pm 35.1$ & $274.6 \pm 104.8$ & $86.6 \pm 38.4$ & $216.7 \pm 98.4$ & $155.9 \pm 63.4$ & $56.6 \pm 17.7$ & $26.2 \pm 13.7$ & $25.4 \pm 11.9$ & $332.6 \pm 87.6$ & $203.6 \pm 80.1$ \\
\hline & 2 & $77.8 \pm 27.4$ & $125.3 \pm 35.3$ & $202.3 \pm 58.1$ & $113.8 \pm 47.1$ & $194.3 \pm 68.6$ & $171.2 \pm 64.8$ & $107.6 \pm 32.3$ & $67 \pm 27.3$ & $38.5 \pm 5.4$ & $231.2 \pm 51.5$ & $199.1 \pm 78.1$ \\
\hline & 1 & $87.6 \pm 24.1$ & $97.7 \pm 34.1$ & $147.9 \pm 27.5$ & $93.2 \pm 23.9$ & $93.2 \pm 39$ & $88.8 \pm 27.3$ & $54.8 \pm 17$ & $27.2 \pm 13.4$ & $85.5 \pm 26.8$ & $220.1 \pm 17.3$ & $173.1 \pm 36.1$ \\
\hline South & 2 & $146.8 \pm 26.1$ & $123.6 \pm 27.6$ & $192.6 \pm 21.7$ & $177.5 \pm 39.3$ & $150.5 \pm 32.1$ & $107.6 \pm 29.2$ & $114.5 \pm 23.2$ & $80.5 \pm 29.8$ & $134 \pm 32.7$ & $176.1 \pm 17.6$ & $175.6 \pm 21.1$ \\
\hline
\end{tabular}
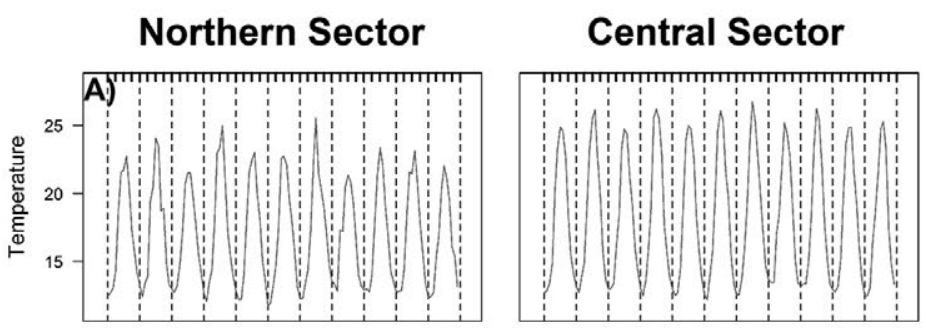

\section{Southern Sector}
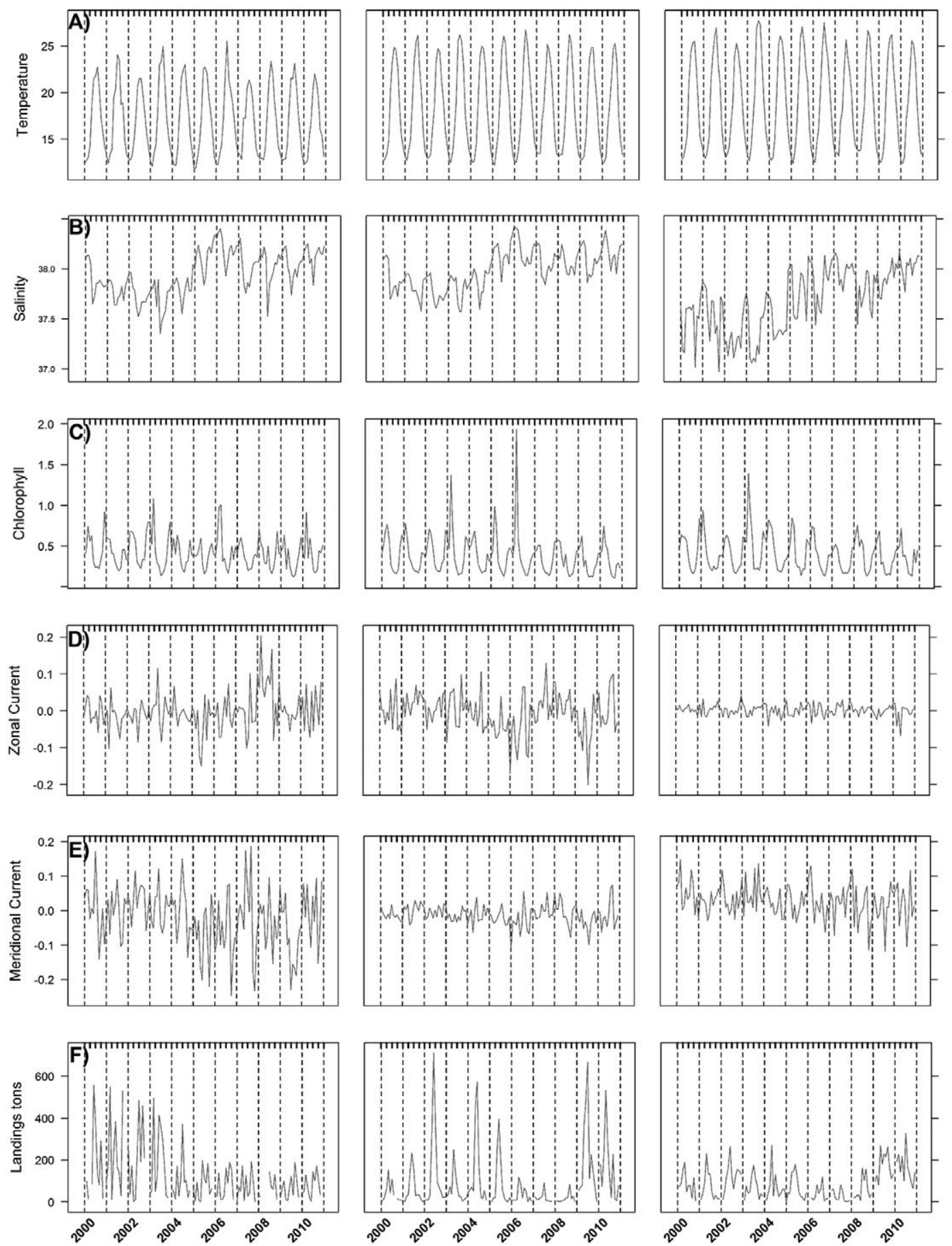

Fig. 3. - Series of monthly values (mean) for each sector. A, the sea surface temperature (SST); B, sea surface salinity (SSS); C, chlorophyll; D, meridional current; E, zonal current; F, anchovy landings during the years 2000-2010. Top ticks indicate the seasons of the year. Note missing data in winter due to the annual close season to protect anchovy recruitment (usually December and January). 
et al. 2010). Depending on the year, between $70 \%$ and $90 \%$ of the landings in number correspond to year 1 or older individuals, i.e. spawning adults.

The explanatory variables used to model the anchovy landings are (Fig. 3): 1) the sea surface temperature (SST in ${ }^{\circ} \mathrm{C}$ ), because it has been shown that it determines the species distribution, enhances the growth of larvae and regulates the onset and the duration of the spawning period (García and Palomera 1996, Palomera et al. 2007); 2) the sea surface salinity (SSS in psu), because previous studies have associated the spawning period and the early life stages of anchovy with low-salinity water (e.g. Lloret et al. 2004, Martín et al. 2008); 3) the chlorophyll $a$ concentration (Chl $a$ in $\mathrm{mg}$ $\mathrm{m}^{-3}$ ) as an indicator of the primary production; 4) the meridional current ( $\mathrm{MC}$ in $\mathrm{m} \mathrm{s}^{-1}$, north to south); and 5) the zonal current ( $\mathrm{ZC}$ in $\mathrm{m} \mathrm{s}^{-1}$, west to east). Both the $\mathrm{MC}$ and the $\mathrm{ZC}$ are involved in larva, egg and prey retention and transport (Sabatés et al. 2007a).

The above environmental variables were derived from satellite data with a monthly time resolution and a space resolution of $1 / 16^{\circ} \times 1 / 16^{\circ}$ developed within the EU-funded project MyOcean (http://marine.copernicus.eu/). All monthly satellite images were merged to obtain aggregate amounts by sector, using ArcGIS software (ESRI 1994).

\section{Statistical analysis}

GAMs (Hastie and Tibshirani 1990, Wood 2006) were used to assess the effect of environmental conditions on the monthly LPUE of the spawning period (May-Oct), log-transformed, in the three sectors (Northern, Central and Southern) from 2000 to 2010. One model for each zone was constructed. Using the backward selection, the best model for each sector was selected based on the minimization of generalized cross-validation criterion (GCV) (Craven and Wahba 1979), which is an estimate of the model's predictive performance and aims at optimizing the trade-off between the model's parsimony (the number of parameters) and goodness of fit.

We used the Gaussian probability distribution as an error distribution and the identity as a link function (Wood 2006), checking the residuals of the model visually for normality and homogeneity, to assess the appropriateness of the choice of probability distribution function. The univariate penalized cubic spline was used as a smoother, and the maximum degree of freedom measured as number of knots $(\mathrm{k})$ was limited to $\mathrm{k}=5$ to avoid over-fitting. For each of the best models obtained we also explored the interaction effect between the time and the other covariates using threshold GAM (TGAM) (Ciannelli et al. 2004).

In practice, the TGAM algorithm divides the time (defined as the month expressed in number, in the year), representing the 'threshold variable', into two levels (i.e. a factor variable), before and after the threshold value (Tv). By introducing in the model the interaction between time and another covariate, the covariate effect can change during the observed period. Hence, through this model formulation, the shape of the smoothing function of each covariate was allowed to change over two contrasting periods defined by $\mathrm{Tv}$. The identification of the threshold value was obtained by defining a search grid over an interval given by the 15 th to 85 th percentiles of the variable time, and the value within this range that produced the model that minimized the GCV score was selected (for details please see Ciannelli et al. 2004).

We used the genuine cross-validation ( $\mathrm{gCV}$ ) to directly compare the selected TGAM and the corresponding GAM models. We calculated gCV scores by excluding randomly about $15 \%$ of the entire dataset and using the remaining data to fit a candidate model, and the mean-squared predictive error was estimated (Ciannelli et al. 2004). The routine was repeated 500 times, with the final $\mathrm{gCV}$ being the average meansquared predictive error of all runs for each candidate model (Ciannelli et al. 2004). All the analyses were performed with $\mathrm{R}$ v. 2.0.1 statistical package (http:// www.r-project.org/).

\section{RESULTS}

\section{Environmental conditions}

The environmental data show that the SST has a clear seasonal pattern (Fig. 3A): the maxima during summer show high variability along the latitudinal gradient, decreasing from south to north. For all sectors, the years 2003 and 2006 are the ones with the highest temperatures, while from the year 2007 SST showed a decrease, especially during spring and summer and more evident in the Northern sector. During cold seasons (winter and autumn) SST showed lower variability between the three sectors, with very similar minima. SSS also showed clear latitudinal differences (Fig. 3B), with lower values in the Southern sector. Although salinity did not show a clear seasonal pattern, we observed lower peaks in late summer and early autumn, more evident in the Southern sector, due to the direct influence of river runoff in this period of the year. Salinity increase was evident from 2004 to 2007 in all areas, followed by a gradual stabilization (Fig. 3B), and 2006 showed higher salinity than the other periods (Fig. 3B). Chl $a$ showed the highest peaks in winter and the second-highest in autumn (Fig. 3C). The Central and Southern sectors show the highest production of $\mathrm{Chl} a$, with the highest value in the Central sector in winter 2006.

Along the Catalan coast, the zonal current showed a velocity of 5 to $15 \mathrm{~cm} \mathrm{~s}^{-1}$ (Fig. 3D). The Southern sector was characterized mainly by an inshore-offshore flow (eastward flow, positive values), except in 2009 and 2010, which were characterized mainly by a westward flow (negative values, Fig. 3F). During the first half of the decade, in the Central sector currents were slow in both directions, persisting in the range of -5 and $5 \mathrm{~cm}$ $\mathrm{s}^{-1}$ until the beginning of 2005 (Fig. 3D). Afterwards, alternating high eastward and westward velocities characterized this sector, with the strongest westward current during the spring of 2009. The Northern sector followed the same pattern as the Central one, but in this case the highest velocity was the eastward one, 


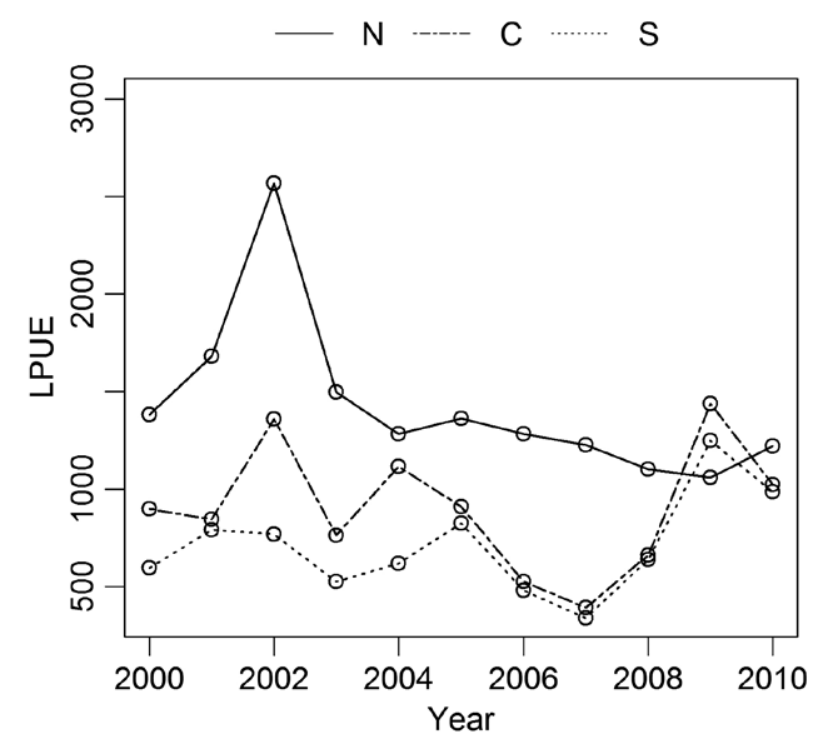

Fig. 4. - Anchovy LPUE during the spawning season (from May to October) for each sector during the years 2000-2010. N, Northern sector; $\mathrm{C}$, Central sector; S, Southern sector.

reaching the uppermost peak in spring 2008 (Fig. 3D). Intense meridional current with high northward and southward current velocities characterized the Northern sector, while in the other two sectors velocities in both directions did not exceed $10 \mathrm{~cm} \mathrm{~s}^{-1}$ (Fig. 3E).

\section{Anchovy LPUE}

The LPUE by sector is shown in Figure 3F. In 2000-2008 LPUE was more than twice as high in the Northern sector than in the Central and Southern sectors, while after 2008 it decreased to values closer to the Southern and Central sectors (Fig. 3F). Considering the overall LPUE during spawning periods in each year from 2000 to 2010, all sectors showed decreasing trends starting in 2002, but during 2009-2010 both the Central and Southern sectors showed an increase (Fig. $4)$. The reduction in abundance was more marked in the Northern sector, with no evidence of recovery. In the Central and Southern sectors the abundances were lower than in the Northern sector and showed a similar decreasing trend until 2008, after which they increased (Fig. 4).

\section{Environmental influence on spawning season}

The threshold model (TGAM) was selected for the Northern sector, while standard GAM models were selected for the other two sectors based on the genuine cross-validation criteria.

The following threshold GAM was the best model fit in the Northern sector:

$$
\begin{gathered}
\log (\text { LPUE })= \\
\left\{\begin{array}{c}
\alpha+g_{1}(\text { SSS })+f_{1}(\text { CHL })+s_{1}(\text { SST })+\varepsilon \text { if time } \leq \text { June } 2007 \\
\alpha+g_{1}(\text { SSS })+f_{1}(\text { CHL })+s_{2}(\text { SST })+\varepsilon \text { if time }>\text { June } 2007
\end{array}\right.
\end{gathered}
$$

This TGAM formulation, formed by two additive model formulations where $\alpha$ is the intercept while $\mathrm{g}_{1}$, $\mathrm{f}_{1}, \mathrm{~s}_{1}, \mathrm{~s}_{2}$ are the non-parametric smoothing functions specifying the effect of the environmental covariates, showed better results than the corresponding GAM model, with a reduction of the $\mathrm{gCV}$ from 0.43 to 0.30 after including time as threshold variable. The TGAM model explained $61.4 \%$ of the deviance (Table 2 ). The effect of the SST changed during the period considered (the smoothing function switched from $s_{1}$ to $s_{2}$ ) and the threshold value estimated for time was at the beginning of the spawning season in 2007 (June), as depicted on the GCV profile in Figure 5.

All partial effects are shown in Figure 6A, B, C, D. Results showed a positive effect of the SSS for values lower than ca. 37.7, followed by a small negative effect at values between ca. 37.7 and 38.1 (Fig. 6A). The effect of Chl $a$ was linear, and became negative for values higher than $0.3 \mathrm{mg} \mathrm{m}^{-3}$ (Fig. 6B). The effect of temperature as described above changed during the period considered. From May 2000 to May 2007 it was positive between ca. 17.5 and ca. $21.3^{\circ} \mathrm{C}$, with a peak at ca. $19^{\circ} \mathrm{C}$ corresponding to spring conditions, and clearly negative at temperatures higher than ca. $21.3^{\circ} \mathrm{C}$ (Fig. 6C). In the period between June 2007 and October 2010, a linear positive effect was observed for temperatures lower than $19^{\circ} \mathrm{C}$, whereas above this value a small negative effect was observed (Fig. 6D).

The following model was the final GAM selected for the Central sector (37.2\% of deviance explained) (Table 2):

$$
\log (\mathrm{LPUE})=\alpha+\mathrm{g}_{1}(\mathrm{SSS})+\mathrm{f}_{1}(\mathrm{ZC})+\mathrm{s}_{1}(\mathrm{CHL})+\varepsilon
$$

where $\alpha$ is the intercept, $g_{1}, f_{1}, s_{1}$ the smoothing functions and $\varepsilon$ the error term. Relatively low SSS values positively affected LPUE within a range starting from ca. 37.6 to ca. 37.83 with a local peak at ca. 37.7 (Fig. $6 \mathrm{E})$. Negative effects were evident for both high eastand westward velocities of the zonal current. Although less evident, low westward velocities at values around $-0.05 \mathrm{~m} \mathrm{~s}^{-1}$ affected the LPUE positively, while no evident effects were present at low eastward velocity

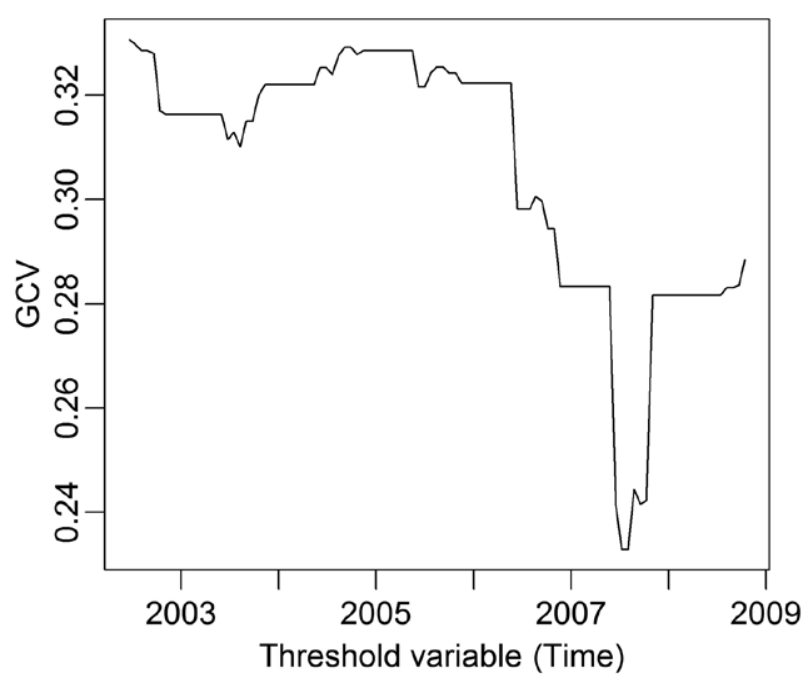

Fig. 5. - GCV profile for the threshold estimation for the variable time in the Northern sector. 

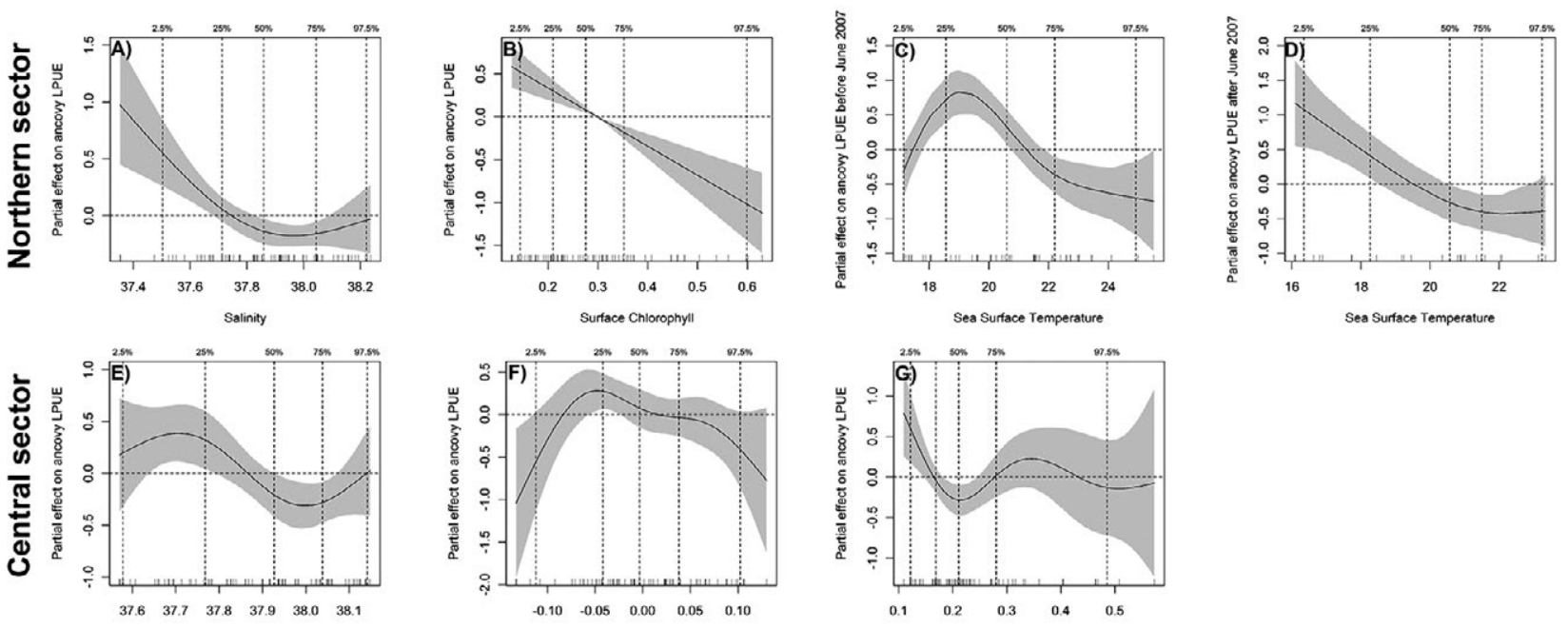

Zonal Current
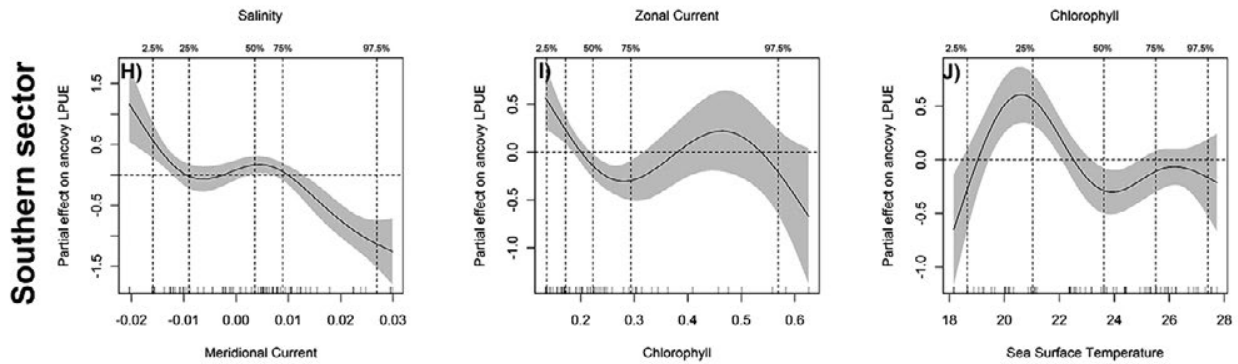

Fig. 6. - Partial effects of sea surface temperature, sea surface salinity, chlorophyll $a$ concentration, meridional current and zonal current for each sector during spawning periods. The median, 1st and 3rd quartiles and 95\% distribution of the explanatory variables are shown along the $\mathrm{x}$-axis as vertical grey lines. The shades areas indicate the $95 \%$ confidence interval. A,B,C,D, partial effects on LPUE in the Northern sector, where C and D are the partial effect of the sea surface temperature before and after June 2007, respectively; E,F,G, partial effects on LPUE in the Central sector; H,I,J, partial effects on LPUE in the Southern sector. See models in Table 2.

Table 2. - Genuine cross-validation scores ( $\mathrm{gCV}$ ) used to select the models in each sector with the best prediction performance among candidate models and \% of the deviance explicated (DVe \%). The final models are indicated in bold text with the analysis of deviance of the covariates (SSS, sea surface salinity; SST, sea surface temperature; CHL, Chlorophyll concentration; ZC, zonal current velocity; MC, meridional current velocity).

\begin{tabular}{|c|c|c|c|c|c|c|c|c|}
\hline Sector & Model & Formulation & $\mathrm{gCV}$ & DVe $\%$ & Edf & \multicolumn{3}{|c|}{ Null DV Res. DV GCV } \\
\hline \multirow[t]{2}{*}{ North } & GAM & $\log ($ LPUE $)=\alpha+g_{1}($ SSS $)+\mathrm{f}_{1}(\mathrm{CHL})+\mathrm{s}_{1}(\mathrm{SST})+\varepsilon$ & 0.43 & $34.6 \%$ & \multirow[b]{2}{*}{$\begin{array}{c}\mathrm{g}_{1}(\mathrm{SSS})=3.049 \\
\mathrm{f}_{1}(\mathrm{CHL})=\mathbf{1} \\
\mathrm{s}_{\mathbf{1}}(\mathrm{SST})=\mathbf{2 . 2 6 4} \\
\mathrm{s}_{2}(\mathrm{SST})=\mathbf{3 . 7 2 7}\end{array}$} & \multirow[b]{2}{*}{0.42} & \multirow[b]{2}{*}{0.19} & \multirow[b]{2}{*}{0.23} \\
\hline & TGAM & $\begin{array}{l}\log (\text { LPUE })=\alpha+g_{1}(\text { SSS })+f_{1}(\text { CHL })+s_{1}(\text { SST })+\varepsilon \text { if time } \leq r \\
\log (\text { LPUE })=\alpha+g_{2}(\text { SSS })+f_{1}(\text { CHL })+s_{1}(\text { SST })+\varepsilon \text { if time }>r \\
\log (\text { LPUE })=\alpha+g_{1}(\text { SSS })+f_{1}(\text { CHL })+s_{1}(\text { SST })+\varepsilon \text { if time } \leq r \\
\log (\text { LPUE })=\alpha+g_{1}(\text { SSS })+f_{2}(\text { CHL })+s_{1}(\text { SST })+\varepsilon \text { if time }>r \\
\log (\text { LPUE })=\alpha+\mathbf{g}_{1}(\text { SSS })+\mathbf{f}_{1}(\text { CHL })+\mathbf{s}_{1}(\text { SST })+\varepsilon \text { if time } \leq \mathbf{r} \\
\log (\text { LPUE })=\alpha+\mathbf{g}_{\mathbf{1}}(\text { SSS })+\mathbf{f}_{\mathbf{1}}(\mathbf{C H L ~})+\mathbf{s}_{\mathbf{2}}(\text { SST })+\varepsilon \text { if time }>\mathbf{r}\end{array}$ & $\begin{array}{l}0.94 \\
\mathbf{0 . 3 0}\end{array}$ & $\begin{array}{l}55.2 \% \\
45.7 \% \\
\mathbf{6 1 . 4 \%}\end{array}$ & & & & \\
\hline \multirow[t]{2}{*}{ Centre } & GAM & $\log (\mathrm{LPUE})=\alpha+\mathrm{g}_{1}(\mathrm{SSS})+\mathrm{f}_{1}(\mathrm{ZC})+\mathrm{s}_{1}(\mathrm{CHL})+\varepsilon$ & 0.70 & $37.2 \%$ & \multirow[b]{2}{*}{$\begin{array}{c}g_{1}(\mathrm{SSS})=2.761 \\
\mathrm{f}_{1}(\mathrm{ZC})=3.437 \\
\mathrm{~s}_{1}(\mathrm{CHL})=\mathbf{3 . 6 2 6}\end{array}$} & \multirow[b]{2}{*}{0.53} & \multirow[b]{2}{*}{0.39} & \multirow[b]{2}{*}{0.54} \\
\hline & TGAM & $\begin{array}{l}\log (\text { LPUE })=\alpha+g_{1}(\text { SSS })+f_{1}(\text { ZC) })+s_{1}(\text { CHL })+\varepsilon \text { if time } \leq r \\
\log (\text { LPUE })=\alpha+g_{2}(\text { SSS })+f_{1}(\text { ZC })+s_{1}(\text { CHL })+\varepsilon \text { if time }>r \\
\log (\text { LPUE })=\alpha+g_{1}(\text { SSS })+f_{1}(\text { ZC })+s_{1}(\text { CHL })+\varepsilon \text { if time } \leq r \\
\log (\text { LPUE })=\alpha+g_{1}(\text { SSS })+f_{2}(\text { ZC })+s_{1}(\text { CHL })+\varepsilon \text { if time }>r \\
\log (\text { LPUE })=\alpha+g_{1}(\text { SSS })+f_{1}(\text { ZC })+s_{1}(\text { CHL })+\varepsilon \text { if time } \leq r \\
\log (\text { LPUE })=\alpha+g_{1}(\text { SSS })+f_{1}(\text { ZC })+s_{2}(\text { CHL })+\varepsilon \text { if time }>r\end{array}$ & $\begin{array}{l}0.74 \\
0.90\end{array}$ & $\begin{array}{l}36.2 \% \\
44.3 \% \\
43.4 \%\end{array}$ & & & & \\
\hline \multirow[t]{2}{*}{ South } & GAM & $\log (\mathrm{LPUE})=\alpha+\mathrm{g}_{1}(\mathrm{MC})+\mathrm{f}_{1}(\mathrm{CHL})+\mathrm{s}_{1}(\mathrm{SST})+\varepsilon$ & 0.30 & $56.1 \%$ & \multirow[b]{2}{*}{$\begin{array}{c}\mathrm{g}_{1}(\mathrm{MC})=2.761 \\
\mathrm{f}_{1}(\mathrm{CHL})=3.437 \\
\mathrm{~s}_{1}(\mathrm{SST})=\mathbf{3 . 6 2 6}\end{array}$} & \multirow[b]{2}{*}{0.33} & \multirow[b]{2}{*}{0.18} & \multirow[b]{2}{*}{0.22} \\
\hline & TGAM & $\begin{array}{l}\log (\text { LPUE })=\alpha+g_{1}(\text { MC })+\mathrm{f}_{1}(\text { CHL })+\mathrm{s}_{1}(\text { SST })+\varepsilon \text { if time } \leq \mathrm{r} \\
\log (\text { LPUE })=\alpha+\mathrm{g}_{2}(\text { MC })+\mathrm{f}_{1}(\text { CHL })+\mathrm{s}_{1}(\text { SST })+\varepsilon \text { if time }>\mathrm{r} \\
\log (\text { LPUE })=\alpha+\mathrm{g}_{1}(\text { MC })+\mathrm{f}_{1}(\text { CHL })+\mathrm{s}_{1}(\text { SST })+\varepsilon \text { if time } \leq \mathrm{r} \\
\log (\text { LPUE })=\alpha+\mathrm{g}_{1}(\text { MC })+\mathrm{f}_{2}(\text { CHL })+\mathrm{s}_{1}(\text { SST })+\varepsilon \text { if time }>\mathrm{r} \\
\log (\text { LPUE })=\alpha+\mathrm{g}_{1}(\text { MC })+\mathrm{f}_{1}(\text { CHL })+\mathrm{s}_{1}(\text { SST })+\varepsilon \text { if time } \leq \mathrm{r} \\
\log (\text { LPUE })=\alpha+\mathrm{g}_{1}(\text { MC })+\mathrm{f}_{1}(\text { CHL })+\mathrm{s}_{2}(\text { SST })+\varepsilon \text { if time }>\mathrm{r}\end{array}$ & 0.34 & $\begin{array}{l}52.6 \% \\
56.3 \% \\
53.6 \%\end{array}$ & & & & \\
\hline
\end{tabular}

values (Fig. 6F). Moderate positive effects were found at values below $0.2 \mathrm{mg} \mathrm{m}^{-3}$ of $\mathrm{Chl} a$ concentration, and a negative effect was found at higher values, excluding the presence of a local non-significant, positive peak at a concentration of $0.35 \mathrm{mg} \mathrm{m}^{-3}$ (Fig. 6G).

The final GAM for the Southern sector explained $56.1 \%$ of the total deviance (Table 2): $\log (\mathrm{LPUE})=\alpha+\mathrm{g}_{1}(\mathrm{MC})+\mathrm{f}_{1}(\mathrm{CHL})+\mathrm{s}_{1}(\mathrm{SST})+\varepsilon$

with $\alpha$ representing the intercept, $g_{1}, f_{1}, s_{1}$ the smoothing functions and $\varepsilon$ the errors. LPUE was positively related to meridional current velocity at values lower than $-0.01 \mathrm{~m} \mathrm{~s}^{-1}$ (i.e. north-to-south flow of $0.01 \mathrm{~m} \mathrm{~s}^{-1}$ or higher) and negatively related to the intensification 
of the meridional current velocity, particularly at values higher than $0.01 \mathrm{~m} \mathrm{~s}^{-1}$, while it showed no effects in the range between ca. $-0.01 \mathrm{~m} \mathrm{~s}^{-1}$ and ca. $0.01 \mathrm{~m} \mathrm{~s}^{-1}$ (Fig. $6 \mathrm{H}$ ). The relationship with Chl $a$ was similar to that observed in the Central sector, with a local peak for concentration equal to $0.35 \mathrm{mg} \mathrm{m}^{-3}$, and a slightly positive effect below a Chl $a$ concentration of $0.2 \mathrm{mg}$ $\mathrm{m}^{-3}$ (Fig. 6I). Positive effects of SST were evident between ca. $19^{\circ} \mathrm{C}$ and $22^{\circ} \mathrm{C}$ with a peak at ca. $21^{\circ} \mathrm{C}$ (Fig. $6 \mathrm{~J})$, while no evident effects on LPUE were found for higher values of SST.

\section{DISCUSSION}

In this study we investigated the relationships between anchovy LPUE and the local environmental variables on the Catalan coast during the spawning period. The strong influence of environmental factors on small pelagic adult populations is well known, particularly the influence on the location and timing of their reproduction (Lloret et al. 2004, Palomera et al. 2007, Giannoulaki et al. 2013) and on the survival of the early life stages (e.g. Agostini and Bakun 2002, Sabatés et al. 2007b, Maynou et al. 2014). In fact, pelagic eggs and larvae need favourable environmental conditions in order to enhance the probability of success (Bakun 1996). During the period considered, i.e. 2000-2010, anchovy LPUEs showed high fluctuations, with minimum values between 2007 and 2008. The LPUE during the year showed seasonality typical of the species in the Mediterranean Sea, with maxima mainly in spring-summer and minima in late autumn-winter. In this area the anchovy spawning period overlaps with the main fishing season for this species, in spring/summer. During this period catches are composed mainly of individuals of the 1- and 2-year cohort (Pertierra and Lleonart 1996, Cardinale et al. 2010), so peaks in landings can be considered as an index of spawning stock biomass, which in this short-lived species is closely related to recruitment to the fishery from the previous year's spawn (as argued by Lloret et al. 2004, Martín et al. 2008).

The relative lower SSTs (below $22^{\circ} \mathrm{C}$ ) in which high abundance of the anchovy population was found can be indicative of nutrient enrichment processes such as wind mixing or river runoff, which are often associated with favourable conditions for fish. The relationships with temperature found in our results are in accordance with that described by other studies in the same area, using different methodologies (e.g. García and Palomera 1996, Lloret et al. 2004, Palomera 1992, Palomera et al. 2007, Martín et al. 2008). Moreover they also agree with results of Somarakis and Nikolioudakis (2007) and Basilone et al. $(2006,2013)$ in the Aegean Sea and in the Straits of Sicily, respectively, highlighting the synchrony between the seasonal reproductive cycle and temperature. This synchrony could be a strategy to enhance the probability of success of larval survival, which is favoured by the subsequent stable sea conditions promoting the prey aggregations (Lasker 1981, Basilone et al. 2006). In fact, these temperatures in the Catalan Sea correspond to the period (late April-May, when anchovy starts spawning) immediately before the stratified season (e.g. Palomera et al. 2007, Giannoulaki et al. 2013). Specifically, in the Southern sector higher LPUEs were found at temperatures between $19^{\circ} \mathrm{C}$ to $22^{\circ} \mathrm{C}$, while in the Northern sector LPUE was higher at temperature between $18^{\circ} \mathrm{C}$ and $21^{\circ} \mathrm{C}$ and below $19^{\circ} \mathrm{C}$, before and after 2007, respectively. The identification of optimal temperature values for the anchovy spawners by several authors (e.g. Motos et al. 1996, García and Palomera 1996, Palomera et al. 2007) may lead one to suppose that stable temperatures are a favourable factor for the reproductive season of anchovies. The northernmost part of the region is characterized by a shorter spawning season related to the thermal cycle (Palomera and Lleonart 1989) in comparison with the other sectors. The apparent decrease in preferred temperature from 2007, corresponding to the threshold value obtained from our analysis, might have further reduced this period and the thermal window in which spawning aggregation occurs.

Results regarding the relationships of Chl $a$ concentration with the landings were found to be similar in all sectors. The low values of Chl $a$ in late spring and summer, which in this study were associated with higher landings, are typical features of temperate oligotrophic areas such as the Mediterranean Sea (Estrada et al. 1985). In fact, the strong runoffs during early spring from Mediterranean rivers, enhancing the surface primary productivity and the subsequent production of zooplankton (the main food for anchovies) (Tudela and Palomera 1995, Tudela et al. 2002), are followed by a stabilization of the water masses and by the development of the thermocline, which inhibits vertical mixing and determines the depletion of nutrients at the surface (Palomera et al. 2007).

Hydrographic variability influences the spatiotemporal extent of spawning habitat, producing large fluctuations in the recruitment of small pelagic fish (Planque et al. 2007). Our results show that salinity lower than 37.8 enhances the LPUE in the two northernmost areas, closer to the Gulf of Lions, and that this variable is the first to be selected in the models (Fig. 6). During the study period in the Catalan Sea, an alternation between years of high and low salinity was observed, similar to those described by Nicolle et al. (2009) in the Gulf of Lions. This alternation could have reduced the suitable habitat for spawning both spatially and temporally, negatively influencing the fish aggregation for reproduction that takes place along the Catalan coast (Palomera 1992, García and Palomera 1996, Palomera et al. 2007). The influence of salinity on preferred habitat during the spawning might be complex because the survival of larvae results from an interaction between several environmental variables (e.g. temperature, dissolved oxygen, currents, salinity, Chl $a$ concentration) (Fréon et al. 2005) and predation. Nevertheless, our results confirm that salinity is important for anchovy, as previously shown by results from echo-survey, egg collection and commercial catch samples in the Mediterranean Sea (e.g. Bellido et al. 2008, Sabatés et al. 2007b), the Bay of Biscay (Massé et al. 1995, Motos et al. 1996, Planque et al. 2007) and the Black Sea (Lisovenko and Andrianov 1996). 
The importance of SSS is evident in the Northern (Deviance explained $=21.5 \%$, Fig. 6A) and Central sectors (Deviance explained $=11.5 \%$, Fig. $6 \mathrm{E}$ ), where low values positively affected anchovy abundances. Our results agree with those of Sabatés et al. (2007b), who found that a gradual decrease in larva and egg concentration occurred towards the south along the Catalan coast when water is extremely salty. They also agreed with previous studies that characterized the spawning habitat, relating anchovy eggs and larvae proliferation to low-salinity periods in the NW Mediterranean Sea (Palomera and Sabatés 1990, Palomera 1992, Martín et al. 2008, Sabatés et al. 2007b, Maynou et al. 2014), and in the Aegean sea (Somarakis and Nikolioudakis 2007), while in the Bay of Biscay salinity was identified as a modest driver of anchovy spawning (Planque et al. 2007) and in the Black Sea anchovy spawning occurs in mesohaline conditions (Lisovenko and Andrianov 1996).

Moreover, we found that other hydrological variables (i.e. currents flowing towards the coast, Fig. 6F) also helped explain the LPUE variability during the spawning periods. The zonal and meridional currents were important environmental drivers in both the Central and Southern sectors, explaining $15.7 \%$ (Fig. 6F) and $19.9 \%$ (Fig. $6 \mathrm{H}$ ) of the total deviance, respectively. In the Central sector, negative zonal currents imply water flow towards the coast, facilitating the retention of spawning aggregations, while in the Southern sector negative values of the meridional current suggest northto-south flow, facilitating retention towards the Ebro Delta area. Retention of eggs and larvae produced by spawning aggregations has been identified as one of the three key processes favouring reproductive success in small pelagic fish (the other two processes of the triad being enrichment and concentration, Bakun 1996).

Overall, mesoscale structures facilitating the aggregation of spawners and highly productive low-salinity waters have been identified as important pelagic conditions for early life stage fish survival and growth (e.g. Lloret et al. 2004, Bakun et al. 2006, Santojanni et al. 2006, Sabatés et al. 2007a). Thus, the match in timing and location between these favourable conditions and the various stages of the life cycle could be crucial in the dynamics of the population. Though LPUE is only an approximation of fish abundance, its analysis improves the understanding of the relationship between small pelagics and the environmental conditions. Specifically, our study confirms the importance of low temperature for the spawning period, in accordance with previous observations, and provides further evidence on the dependence of anchovy adult population on specific oceanographic variables, i.e. salinity and current velocity.

\section{ACKNOWLEDGEMENTS}

Federico Quattrocchi was financially supported by a fellowship of the CNR (Consiglio Nazionale delle Ricerche) in collaboration with Dr. Germana Garofalo. Part of this study was also financed by the European Commission through the H2020 Research and Inno- vation Action 'MINOUW: Science, technology and society initiative to minimize unwanted catches in European fisheries', contract n ${ }^{\circ} 634495$.

\section{REFERENCES}

Agostini V.N., Bakun A. 2002. 'Ocean triads' in the Mediterranean Sea: physical mechanisms potentially structuring reproductive habitat suitability (with example application to European anchovy, Engraulis encrasicolus). Fish. Oceanogr. 11: 129-142. http://dx.doi.org/10.1046/j.1365-2419.2002.00201.x

Alheit J., Pohlmann T., Casini M., et al. 2012. Climate variability drives anchovies and sardines into the North and Baltic Seas. Progr. Oceanogr. 96: 128-139. http://dx.doi.org/10.1016/j.pocean.2011.11.015

Bakun A. 1996. Patterns in the ocean: ocean processes and marine population dynamics. California Dea Grant College System, C.A. 323 pp.

Bakun A. 2006. Fronts and eddies as key structures in the habitat of marine fish larvae: opportunity, adaptive response and competitive advantage. Sci. Mar. 70: 105-122. http://dx.doi.org/10.3989/scimar.2006.70s2105

Basilone G., Guisande C., Patti B., et al. 2006. Effect of habitat conditions on reproduction of the European anchovy (Engraulis encrasicolus) in the Strait of Sicily. Fish. Oceanogr. 15: 271-280. http://dx.doi.org/10.1111/j.1365-2419.2005.00391.x

Basilone G., Bonanno A., Patti B., et al. 2013. Spawning site selection by European anchovy (Engraulis encrasicolus) in relation to oceanographic conditions in the Strait of Sicily. Fish. Oceanogr. 22: 309-323. http://dx.doi.org/10.1111/fog.12024

Bellido J.M., Brown A.M., Valavanis V.D., et al. 2008. Identifying essential fish habitat for small pelagic species in Spanish Mediterranean waters. Hydrobiologia 612: 171-184. http://dx.doi.org/10.1007/s10750-008-9481-2

Calvo E., Simó R., Coma R., et al. 2012. Effects of climate change on Mediterranean marine ecosystems: the case of the Catalan Sea. Clim. Res. 50: 1-29. http://dx.doi.org/10.3354/cr01040

Cardinale M., Cheilari A., Raetz H.J. 2010. Scientific, Technical and Economic Committee for Fisheries (STECF). In: Assessment of Mediterranean stocks-Part 1. JRC Publications Repository. Publications Office of the European Union. http://dx.doi.org/10.2788/59974

Castellón A., Font J., García E. 1990. The Liguro-Provençal-Catalan current (NW Mediterranean) observed by Doppler profiling in the Balearic Sea. Sci. Mar. 54: 269-276.

Ciannelli L., Chan K.S., Bailey K.M., et al. 2004. Nonadditive effects of the environment on the survival of a large marine fish population. Ecology 85: 3418-3427. http://dx.doi.org/10.1890/03-0755

Craven P., Wahba G. 1979. Smoothing noisy data with spline functions: estimating the correct degree of smoothing by the method of generalized cross-validation. Numer. Mat. 31: 377-403. http://dx.doi.org/10.1007/BF01404567

Cury P., Roy C. 1989. Optimal environmental window and pelagic fish recruitment success in upwelling areas. Can. J. Fish. Aquat. Sci. 46: 670-680. http://dx.doi.org/10.1139/f89-086

Cushing D.H. 1990. Plankton production and year-class strength in fish populations: an update of the match/mismatch hypothesis. Adv. Mar. Biol. 26: 249-293. http://dx.doi.org/10.1016/S0065-2881(08)60202-3

ESRI. 1994. ARC Macro Language. Environmental Systems Research Institute Inc, USA: Redlands, CA, pp. 3-37.

Estrada M., Vives F., Alcaraz M. 1985. Life and the productivity of the open sea. In: Margalef R. (ed), Western Mediterranean. Pergamon Press, Oxford: pp. 148-197.

Farrugio H. 2013. Fisheries in the gulf of Lions. UNEP MAP RAC/ SPA. H. Ed. RAC/SPA, Tunis. pp. 79

Fréon P., Cury P., Shannon L., et al. 2005. Sustainable exploitation of small pelagic fish stocks challenged by environmental and ecosystem changes: a review. Bull. Mar. Sci. 76: 385-462.

García A., Palomera I. 1996. Anchovy early life history and its relation to its surrounding environment in the Western Mediterranean basin. Sci. Mar. 60(S2): 155-166.

Giannoulaki M., Iglesias M., Tugores M.P., et al. 2013. Characterising the potential habitat of European anchovy Engraulis encra- 
sicolus in the Mediterranean Sea, at different life stages. Fish. Oceanogr. 22: 69-89.

http://dx.doi.org/10.1111/fog.12005

Hastie T.J., Tibshirani R.J. 1990. Generalized additive models, vol 43. CRC Press.

Houde E. 1997. Patterns and trends in larval stage growth and mortality of teleost fish. J. Fish. Biol. 51: 52-83. http://dx.doi.org/10.1111/j.1095-8649.1997.tb06093.x

Lasker R. 1981. The role of a stable ocean in larval fish survival and subsequent recruitment. In: Lasker R. (ed.), Marine fish larvae: morphology, ecology and relation to fisheries, vol. 1, Univ. Washington Press, Seattle, pp. 80-89.

Lisovenko L.A., Andrianov D.P. 1996. Reproductive biology of anchovy (Engraulis encrasicolus ponticus, Alexandrov 1927) in the Black Sea. Sci. Mar. 60: 209-218.

Lleonart J., Maynou F. 2003. Fish stock assessments in the Mediterranean: state of the art. Sci. Mar. 67: 37-49. http://dx.doi.org/10.3989/scimar.2003.67s137

Lloret J., Lleonart J., Solé I. 2000. Time series modelling of landings in Northwest Mediterranean Sea. ICES J. Mar. Sci. 57: 171-184. http://dx.doi.org/10.1006/jmsc.2000.0570

Lloret J., Lleonart J., Solé I., et al. 2001. Fluctuations of landings and environmental conditions in the north-western Mediterranean Sea. Fish. Oceanogr. 10: 33-50. http://dx.doi.org/10.1046/j.1365-2419.2001.00151.x

Lloret J., Palomera I., Salat J., et al. 2004. Impact of freshwater input and wind on landings of anchovy (Engraulis encrasicolus) and sardine (Sardina pilchardus) in shelf waters surrounding the Ebre (Ebro) River delta (north-western Mediterranean). Fish. Oceanogr. 13: 102-110. http://dx.doi.org/10.1046/j.1365-2419.2003.00279.x

Lluch-Belda D., Crawford R., Kawasaki T., et al. 1989. World-wide fluctuations of sardine and anchovy stocks: the regime problem. S. Afr. J. Mar. Sci. 8: 195-205. http://dx.doi.org/10.2989/02577618909504561

Martín P., Sabatés A. 1991. Spatio-temporal distribution pattern of the red band-fish Cepola rubescens Linnaeus at different stages of its life cycle in the northwestern Mediterranean. J. Fish. Biol. 39: $549-557$. http://dx.doi.org/10.1111/j.1095-8649.1991.tb04385.x

Martín P., Bahamon N., Sabatés A., et al. 2008. European anchovy (Engraulis encrasicolus) landings and environmental conditions on the Catalan Coast (NW Mediterranean) during 20002005. In: Valavanis V.E., Essential Fish Habitat Mapping in the Mediterranean. Series Developments in Hydrobiology, vol. 203: 185-199. Springer. http://dx.doi.org/10.1007/978-1-4020-9141-4_14

Martín P., Sabatés A., Lloret J., et al. 2012. Climate modulation of fish populations: the role of the Western Mediterranean Oscillation (WeMO) in sardine (Sardina pilchardus) and anchovy (Engraulis encrasicolus) production in the north-western Mediterranean. Clim. Chang. 110: 925-939. http://dx.doi.org/10.1007/s10584-011-0091-z

Massé J., Leroy C., Halgand D., et al. 1995. Anchovy adult and egg distribution in the Bay of Biscay in relation to environmental conditions, as observed during acoustic surveys (1990, 1991, 1992). Actas del IV coloquio Internacional sobre Oceanografía del Golfo de Vizcaya: 281- 283. Santander.

Maynou F., Sabatés A., Salat J. 2014. Clues from the recent past to assess recruitment of Mediterranean small pelagic fishes under sea warming scenarios. Clim. Chang. 126: 175-188. http://dx.doi.org/10.1007/s10584-014-1194-0

Millot C. 1991. Mesoscale and seasonal variabilities of the circulation in the western Mediterranean. Dyn. Atmos. Oceans. 15: 179-214. http://dx.doi.org/10.1016/0377-0265(91)90020-G

Motos L., Uriarte A., Valencia V. 1996. The spawning environment of the Bay of Biscay anchovy (Engraulis encrasicolus L.). Sci. Mar. 60: 237-255.

Nicolle A., Garreau P., Liorzou B. 2009. Modelling for anchovy recruitment studies in the Gulf of Lions (Western Mediterranean Sea). Ocean Dynamics 59: 953-968. http://dx.doi.org/10.1007/s10236-009-0221-6

Palomera I. 1992. Spawning of anchovy Engraulis encrasicolus in the Northwestern Mediterranean relative to hydrographic fea- tures in the region. Mar. Ecol. Prog. Ser. 79: 215-223. http://dx.doi.org/10.3354/meps079215

Palomera I., Lleonart J. 1989. Field mortality estimates of anchovy larvae (Engraulis encrasicolus) in the western Mediterranean. J. Fish. Biol. 35 (suppl. A): 133-138. http://dx.doi.org/10.1111/j.1095-8649.1989.tb03054.x

Palomera I., Sabatés A. 1990. Co-occurrence of Engraulis encrasicolus and Sardinella aurita eggs and larvae in the northwestern Mediterranean. Sci. Mar. 54: 61-67.

Palomera I., Olivar M.P., Salat J., et al. 2007. Small pelagic fish in the NW Mediterranean Sea: an ecological review. Prog. Oceanogr. 74: 377-396. http://dx.doi.org/10.1016/j.pocean.2007.04.012

Pertierra J.P. 1992. Biología pesquera de la anchoa Engraulis encrasicolus del Mar Catalán (NW Mediterráneo). PhD thesis, Univ. Politècnica de Catalunya, Barcelona.

Pertierra J.P., Lleonart J. 1996. NW Mediterranean anchovy fisheries. Sci. Mar. 60(Suppl. 2): 257-267.

Planque B., Bellier E., Lazure P. 2007. Modelling potential spawning habitat of sardine (Sardina pilchardus) and anchovy (Engraulis encrasicolus) in the Bay of Biscay. Fish. Oceanogr. 16: 16-30. http://dx.doi.org/10.1111/j.1365-2419.2006.00411.x

Pörtner H.O., Peck M. 2010. Climate change effects on fishes and fisheries: towards a cause-and-effect understanding. J. Fish. Biol. 77: 1745-1779. http://dx.doi.org/10.1111/j.1095-8649.2010.02783.x

Razouls C., Kouwenberg J. 1993. Spatial distribution and seasonal variation of mesozooplankton biomass in the Gulf of Lions (northwestern Mediterranean). Oceanol. Acta 16: 393-401.

Rojas P., Garcia M., Sospedra J., et al. 1995. On the structure of the mean flow in the Blanes Canyon area (NW Mediterranean) during summer. Oceanol. Acta 18: 443-454.

Sabatés A., Olivar M.P., Salat J., et al. 2007a. Physical and biological processes controlling the distribution of fish larvae in the NW Mediterranean. Prog. Oceanogr. 74: 355-376. http://dx.doi.org/10.1016/j.pocean.2007.04.017

Sabatés A., Salat J., Palomera I., et al. 2007b. Advection of anchovy (Engraulis encrasicolus) larvae along the Catalan continental slope (NW Mediterranean). Fish. Oceanogr. 16: 130-141. http://dx.doi.org/10.1111/j.1365-2419.2006.00416.x

Sabatés A., Salat J., Raya V., et al. 2013. Role of mesoscale eddies in shaping the spatial distribution of the coexisting Engraulis encrasicolus and Sardinella aurita larvae in the northwestern Mediterranean. J. Mar. Syst. 111: 108-119. http://dx.doi.org/10.1016/j.jmarsys.2012.10.002

Santojanni A., Arneri E., Bernardini V., et al. 2006. Effects of environmental variables on recruitment of anchovy in the Adriatic Sea. Clim. Res. 31: 181-193. http://dx.doi.org/10.3354/cr031181

Somarakis S., Nikolioudakis N. 2007. Oceanographic habitat, growth and mortality of larval anchovy (Engraulis encrasicolus) in the northern Aegean Sea (eastern Mediterranean). Mar. Biol. 152: 1143-1158. http://dx.doi.org/10.1007/s00227-007-0761-6

Tudela S., Palomera I. 1995. Diel feeding intensity and daily ration in the anchovy Engraulis encrasicolus in the northwest Mediterranean Sea during the spawning period. Mar. Ecol. Prog. Ser. 129: 55-61. http://dx.doi.org/10.3354/meps 129055

Tudela S., Palomera I., Quílez G. 2002. Feeding of anchovy Engraulis encrasicolus larvae in the north-west Mediterranean. J. Mar. Biol. Ass. UK 82: 349-350. http://dx.doi.org/10.1017/S0025315402005568

Vargas-Yáñez M., Moya F., Tel E., et al. 2009. Warming and salting in the western Mediterranean during the second half of the 20th century: inconsistencies, unknowns and the effect of data processing. Sci. Mar. 73: 7-28. http://dx.doi.org/10.3989/scimar.2009.73n1007

Vargas-Yáñez M., Moya F., García-Martínez M., et al. 2010. Climate change in the Western Mediterranean sea 1900-2008. J. Mar. Syst. 82: 171-176. http://dx.doi.org/10.1016/j.jmarsys.2010.04.013

Wood S., 2006. Generalized additive models: an introduction with R. CRC/Taylor and Francis. 